\title{
Evaluation of Temporal Contribution of Groundwater to a Small Lake through Analyses of Water Quantity and Quality
}

\author{
Jeonga Kim ${ }^{1}$, Sung-Wook Jeen ${ }^{1,2, *(\mathbb{C}}$, Jeonghoon Lee ${ }^{3} \mathbb{D}$, Kyung-Seok Ko ${ }^{4}$, Dong-Chan Koh ${ }^{4} \mathbb{D}$, \\ Wonbin Kim ${ }^{2,4}$ and Hojeong Jo ${ }^{2,4}$ \\ 1 Department of Environment and Energy, Jeonbuk National University, Jeonju-si, Jeollabuk-do 54896, Korea; \\ kja6208@gmail.com \\ 2 Department of Earth and Environmental Sciences \& The Earth and Environmental Science System Research \\ Center, Jeonbuk National University, Jeonju-si, Jeollabuk-do 54896, Korea; chucoba365@naver.com (W.K.); \\ choj412@naver.com (H.J.) \\ 3 Department of Science Education, Ewha Womans University, Seoul 03760, Korea; jeonghoon.lee@ewha.ac.kr \\ 4 Groundwater Department, Geologic Environment Division, Korea Institute of Geoscience and Mineral \\ Resources (KIGAM), Daejeon 34132, Korea; kyungsok@kigam.re.kr (K.-S.K.); chankoh@kigam.re.kr (D.-C.K.) \\ * Correspondence: sjeen@jbnu.ac.kr; Tel.: +82-63-270-3429
}

Received: 15 August 2020; Accepted: 13 October 2020; Published: 16 October 2020

\begin{abstract}
Groundwater can flow into or out of surface water and thus can greatly affect the quantity and quality of surface water. In this study, we conducted a water quantity and quality analysis for 11 months in 2018 and 2019 to evaluate the temporal contribution of groundwater to surface water at Osongji, a small lake located in Jeonju-si, Jeollabuk-do, Korea. Groundwater fluxes and groundwater and surface water levels were measured using seepage meters and a piezometer, respectively. On-site water quality parameters, cations, and anions for groundwater and surface water were analyzed. Hydrogen and oxygen isotopes for groundwater, surface water, and rainwater were also analyzed. Groundwater influx did not correlate directly to precipitation, suggesting that it may be delayed after rainwater infiltration. Aqueous chemistry indicated that the hydrogeochemical characteristics of surface water were substantially affected by groundwater. The isotopic composition of surface water changed over time, indicating a different contribution of groundwater in different seasons. This study shows that water quantity and quality data can be used in combination to evaluate temporal changes in the groundwater contribution to surface water.
\end{abstract}

Keywords: groundwater flux; seepage meter; piezometer; aqueous chemistry; hydrogen and oxygen isotopes

\section{Introduction}

Groundwater interacts closely with surface water within the perspective of the water cycle. In recent years, the importance of groundwater baseflow has been increasingly recognized due to the contribution of groundwater to surface water, both in terms of quantity and quality [1,2]. However, groundwater and surface water are often managed separately, and the management of surface water has largely focused on surface runoff, which has an immediate effect on surface water.

The contribution of groundwater flux to surface water varies according to seasonality [3-5]. In the dry season, in particular, the contribution of groundwater baseflow to river flow can be greater than that of direct runoff [6]. Barkle et al. [4] showed that the groundwater contribution to the Pukemanga Stream, in the North Island of New Zealand, varies from 52\% to 74\%, depending on the season. This indicates that surface water flow is maintained primarily by groundwater during the dry season. 
Understanding the groundwater-surface water interaction is important not only for the management of water quantity, but also for water quality. It has been observed that the baseflow of contaminated groundwater can affect surface water quality [7-10]. On the other hand, it has often been observed that the flow of contaminated surface water can affect the quality of groundwater [11]. To ensure the sustainable management of water resources, it is therefore important to quantify the fluxes between groundwater and surface water as well as to evaluate the characteristics of water quality.

Various methods have been used to evaluate the groundwater-surface water interaction, including direct or indirect measurements, the chemical composition approach, hydrograph separation using hydraulic or heat tracers, and numerical modeling [12,13]. The most commonly used direct measurement method is groundwater flux measurements using a seepage meter, originally designed by Lee [14]. Although the measured groundwater flux may only represent the area where seepage meters are installed, they can measure relatively accurate and absolute flux values for the realistic water system, and are thus able to assess the spatial heterogeneity and temporal variability of the groundwater-surface water interaction [15-17]. This method has been used for comparison and calibration with other methods for evaluating the groundwater-surface water interaction $[18,19]$. Indirect measurement methods include groundwater flux estimation from hydraulic gradient and hydraulic conductivity using the Darcy equation [20], temperature, and resistivity [21].

The chemical composition approach, which uses the hydrochemical data for each component of the water system, can also aid in understanding the groundwater-surface water interaction. Even though this method has some difficulties with quantifying mixing ratios that contribute to surface water due to its non-conservative behavior, it is useful for identifying the sources that can affect specific water components or seasonal variations [5,22].

Hydrograph separation, for instance, has been used as a chemical approach in many studies to evaluate the water system by separating its components using low-reactivity tracers. Oxygen and hydrogen isotopes, the Si concentration, and electrical conductivity (EC) are commonly used as tracers. Isotopic hydrograph separation (IHS) has been used since the 1970s [23] and has been further developed recently with the advent of isotope ratio infrared spectroscopy (IRIS) [24,25]. IHS is able to calculate the contribution of groundwater to surface water; however, it can only be applied under the specified conditions $[26,27]$.

The heat tracer method can identify the groundwater-surface water interaction by using the characteristic differences in temperature between groundwater and surface water. Although it has been used in many studies [28,29], the heat tracer method must be used in conjunction with numerical analysis or modeling, or used as a surrogate for other methods [30]. Numerical modeling has been conducted in many studies to simulate groundwater-surface water interactions under various scenarios [31-33]. While modeling can reflect the realistic hydrologic conditions [34], uncertainties remain relating to model parameters.

Since each method has limitations and uncertainties, it is beneficial to combine several methods to evaluate the groundwater-surface water interaction. For example, Woessner and Sullivan [35] measured groundwater flux and hydraulic head differences and compared the results with those of a water quality analysis. In Cey et al.'s study [36], seepage meter measurements and hydrograph separation using oxygen isotopic tracers were used to quantify groundwater discharge to a small stream. Rautio and Korkka-Niemi [19] also used various methods, including seepage meters and chemical and isotopic tracers, to evaluate groundwater-lake water interactions. However, because each site has different hydrogeological characteristics, a different combination of study methods is required to better represent the features of the hydrological system for a specific study site.

In this study, we both measured and analyzed water quantity and quality in order to compensate for the limitations and uncertainties related to existing evaluation methods for studying the groundwater-surface water interaction. The specific purpose of this study was to evaluate the temporal contribution of groundwater to surface water in a stable lake water system. A monthly monitoring of water quantity and quality was conducted at Osongji, a small lake in Jeonju-si, Jeollabuk-do, Korea, 
over a period of 11 months from October 2018 to August 2019. Groundwater flux was measured directly using seepage meters and water levels of groundwater and surface water were measured using a piezometer. On-site water quality parameters, cations and anions analysis, and hydrogen and oxygen isotope analyses were also conducted. Isotope analyses were used to identify the temporal variations in the isotopic composition of surface water and groundwater. Aqueous chemistry data were used to distinguish between the chemical characteristics of groundwater and surface water and to help to understand the groundwater-surface water interaction for the lake system.

\section{Study Area}

The study was conducted Osong lake (known as Osongji in Korean) (35.86 ${ }^{\prime} \mathrm{N}, 127.13^{\prime} \mathrm{E}$ ), a relatively small reservoir located in Jeonju-si, Jeollabuk-do, Korea (Figure 1). The surface water area of Osongji is $29,165 \mathrm{~m}^{2}$, the average depth of the lake is $1.62 \mathrm{~m}$, the water storage is $47,200 \mathrm{~m}^{3}$, and the watershed area is $535,000 \mathrm{~m}^{2}$ [37]. There is no recognizable surface water stream into the lake. Water in Osongji flows from south (upgradient) to north (downgradient) and exits through the outlet located at the lake's northern end, under which a small dam has been constructed to reserve water for agricultural uses. More than 70\% of the Osongji watershed area is used as farmland, with the remainder of the area consisting of forest [37]. Osongji is surrounded by farmland such as orchards-as a result, fertilizers and pesticides used in the watershed area may leach into groundwater or directly into the lake. To date, however, no serious water quality problems or water shortages have been reported. This may be due to the fact that precipitation within the Osongji watershed, with its relatively low topography, is continuously flowing into the lake, thus providing natural drainage [37]. In the previous study of Lee et al. [13], continuous groundwater influx was indicated through the measurement by seepage meters installed in the upgradient area; however, the results were limited to the summer season in 2018.

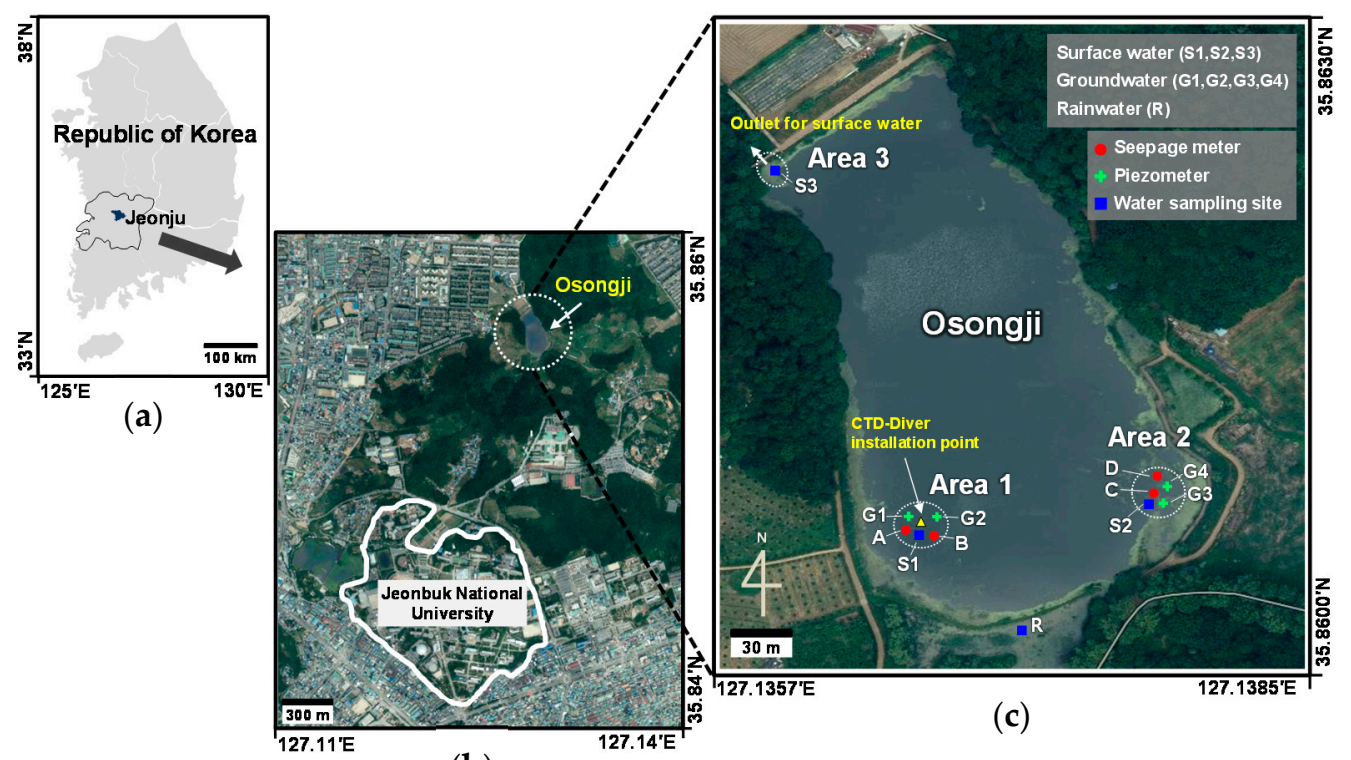

(b)

Figure 1. (a) Map of the Republic of Korea and study site. (b) Inset map showing location of Jeonju-si (city) with Osongji. (c) Satellite photograph of Osongji and locations of seepage meters, piezometers, and surface water and rainwater sampling sites. Groundwater samples were collected from piezometers.

According to the geological map obtained from the Multiplatform GEOscience Information System (MGEO), provided by the Korea Institute of Geoscience and Mineral Resources (KIGAM), the bedrock in the Osongji watershed area consists of various strata. The bedrocks of the surrounding water system consist of two groups of rocks. The rocks composed mainly of quartz schist, limestone, and phyllite are located in the southeast of Osongji, and the other rocks composed of quartz schist and phyllite are 
located in the west. These bedrocks were penetrated by the schistose granite stratum of the Cretaceous Period, and modern sediments (alluvium) cover these strata in the form of unconformity. It is reported that the bedrocks have been severely weathered [37].

Weather data for the study area over the last 5 years (2015-2019) from the Korea Meteorological Administration (KMA) (https:/data.kma.go.kr) show that the annual average temperature is $14.04^{\circ} \mathrm{C}$, while the annual average minimum and maximum temperatures are 9.66 and $19.36^{\circ} \mathrm{C}$, respectively. Annual precipitation is $1036 \mathrm{~mm}$. Precipitation gradually increases from April, with the most concentrated precipitation occurring between July and August. Annual evaporation in Jeonju-si is $835 \mathrm{~mm}$. According to the KMA, the minimum and maximum values for the monthly average evaporation rate during the study period were $1.1 \mathrm{~mm} /$ day in December 2018 and $4.7 \mathrm{~mm} /$ day in May 2019, respectively.

\section{Methods}

\subsection{Field Methods}

The field investigation was carried out at Osongji once a month for 11 months from October 2018 to August 2019. For measurement of groundwater fluxes and water quality analysis, Area 1 and Area 2 in the upgradient of the lake, and Area 3 in the vicinity of the outlet for surface water were selected. Four seepage meters, manufactured for the study of Jo and Jeen [38], were used to measure groundwater flux. The seepage meters were installed in the relatively flat sedimentary layer in both Area 1 and Area 2, and identified as A, B, C, and D (Figure 1c). The seepage meter was made of steel, with a cylindrical shape (height of $25 \mathrm{~cm}$ and diameter of $58 \mathrm{~cm}$ ) and a $5-\mathrm{cm}$ diameter outlet at the top. A rubber stopper (top diameter of $5.5 \mathrm{~cm}$ and base diameter of $5 \mathrm{~cm}$ ), with a hole in the center, was inserted into the outlet, and a Teflon tube (PTFE) (outer diameter of $1 \mathrm{~cm}$ and inner diameter of $0.8 \mathrm{~cm}$ ) was inserted into the center of the rubber stopper. After connecting the Teflon tube to a collection bag, groundwater flux was determined by measuring changes in the water volume in the collection bag over a given time period. Time periods for flux measurement were typically around 3 days. Groundwater flux was calculated by dividing the volume of water collected during a given measurement period by the sectional area $\left(0.26 \mathrm{~m}^{2}\right)$ of the seepage meter. Thus, groundwater flux measured by the seepage meter was expressed as the flux per unit area of the seepage meter $(\mathrm{m} / \mathrm{s})$.

A total of four piezometers (total length of $132 \mathrm{~cm}$ and inner diameter of $2.1 \mathrm{~cm}$ ) were installed in the vicinity of each seepage meter to collect groundwater samples for chemical analysis. The screen of the piezometer was located $10 \mathrm{~cm}$ from its bottom end. The length of the screen was $23 \mathrm{~cm}$. The piezometer was installed to a depth of around $50 \mathrm{~cm}$ below the lakebed. The water level was measured automatically using a CTD-Diver (total length of $13.5 \mathrm{~cm}$ and a diameter of $2.2 \mathrm{~cm}$; Van Essen Instruments B.V., Delft, The Netherlands). For measurement with the CTD-Diver, an additional piezometer (total length of $134 \mathrm{~cm}$ and inner diameter of $5 \mathrm{~cm}$ ) was manufactured and installed in Area 1. Groundwater and surface water levels were measured automatically by the CTD-Diver at $1 \mathrm{~h}$ intervals, calibrated by subtracting the atmospheric pressure from the measured pressure values, and the data were interpreted as daily average values.

Grain size analysis was conducted to determine the size distribution of the lake sediment. Lakebed sediments were collected with grab sampling at a depth of approximately $20 \mathrm{~cm}$ below the lakebed in Area 1 and Area 2, and then completely dried at room temperature until the analysis. Grain size analysis was conducted using a ro-tap sieve shaker (Heungin Co., Gimpo, Korea) with sieves (aperture size of $2,1,0.5,0.25,0.125$, and $0.063 \mathrm{~mm}$ ). The weight of particles for each size was measured and calculated as a percentage $(\%)$.

\subsection{Sampling and Analyses}

Groundwater and surface water were collected on a monthly basis for analyses of the on-site water quality parameters, alkalinity, anions and cations, and isotopic compositions. Additionally, rainwater 
was collected for hydrogen and oxygen isotope analysis. Surface water (S1, S2, S3) and groundwater (G1, G2, G3, G4) were collected from each area (Area 1, Area 2, and Area 3) (Figure 1c). Groundwater was collected from the installed piezometers (G1, G2, G3, G4) using a Wattera pump connected with plastic tubing and a foot valve (Wattera Co., Luxembourg) and stored in $250 \mathrm{~mL}$ polyethylene bottles. Surface water was collected from around $30 \mathrm{~cm}$ below the lake surface, and in January 2019, it was collected from the ice layer. For analysis of water stable isotopes, an open polypropylene container (width of $24.5 \mathrm{~cm}$, depth of $17.5 \mathrm{~cm}$, and height of $15 \mathrm{~cm}$ ) was used. To minimize the evaporation of rainwater samples during the sampling period of around one month, the surface of the container was thinly covered with mineral oil (Daejung Chemicals and Metals Co., Ltd., Siheung, Korea).

On-site water quality parameters, including $\mathrm{pH}$, oxidation-reduction potential (ORP), dissolved oxygen (DO), and EC, were measured in the field using a multiparameter meter (Orion star, Thermo Fisher Scientific Inc., USA). A pH probe (Orion 8157BNUMD Ross pH/ATC Electrode, Thermo Fisher Scientific Inc., Waltham, MA, USA) was used for $\mathrm{pH}$ measurement. ORP was measured after calibrating the ORP meter with ZoBell's ORP standard solution (Hach Co., Ltd., Loveland, CO, USA), and expressed as Eh values. All water samples collected for alkalinity, anions, cations, and isotope analysis were filtered through a $0.45 \mu \mathrm{m}$ syringe filter and stored in a $15-\mathrm{mL}$ polyethylene bottle at $4{ }^{\circ} \mathrm{C}$ before analysis. Water samples for alkalinity were titrated with $\mathrm{H}_{2} \mathrm{SO}_{4}(0.16 \mathrm{~N})$ until pH 4.5 endpoint with bromocresol green-methyl red indicator. Anions were analyzed with Dionex ICS-90 ion chromatography (IC) in the Department of Earth and Environmental Sciences at Jeonbuk National University, Korea. Cations were analyzed using inductively coupled plasma-optical emission spectroscopy (ICP-OES; Perkin Elmer Optima 7300 DV). Water stable isotopes were analyzed with Picarro L2120-i IRIS at the Korea Institute of Geoscience and Mineral Resources (KIGAM, Daejeon, Korea). A total of 36 samples of groundwater, 28 samples of surface water, and 8 samples of rainwater were used for water stable isotope analysis. Wavelength-scanned cavity ring-down spectroscopy (WS-CRDS) was used for water stable isotope analysis. Water samples were vaporized at $110^{\circ} \mathrm{C}$ for $90 \mathrm{~s}$, then sent to the optical cavity by $\mathrm{N}_{2}$ gas (purity 99.999\%; gas flow 2.5 psi) for analysis. KWS-N1, KWS-N2, and KWS-D, which were used as working standards in the Reston Stable Isotope Laboratory of the United States Geological Survey (USGS) [24], were used as reference materials to calibrate the stable isotopic compositions.

The compositions of hydrogen and oxygen isotopes are represented as $\delta$ notation relative to the Vienna-Standard Mean Ocean Water (V-SMOW):

$$
\delta^{2} \mathrm{H} \text { or } \delta^{18} \mathrm{O}(\%)=\left[\frac{R_{\text {sample }}}{R_{\text {standard }}}-1\right] \times 1000
$$

where $R$ is the isotopic ratio $\left({ }^{2} \mathrm{H} /{ }^{1} \mathrm{H}\right.$ or $\left.{ }^{18} \mathrm{O} /{ }^{16} \mathrm{O}\right)$. The sample and standard subscripts here refer to the sample and the standard (V-SMOW), respectively. The linear relationship between hydrogen and oxygen isotopes for water samples that have not undergone evaporation is represented by the global meteoric water line (GMWL) [39]:

$$
\delta \mathrm{D}=8 \delta^{18} \mathrm{O}+10
$$

\section{Results and Discussion}

\subsection{Groundwater Flux}

Groundwater flux in Osongji was measured using seepage meters from October 2018 to August 2019 and compared with daily precipitation data from the nearby Songcheon-dong station provided by the KMA (Figure 2). Precipitation data during the study period represents the typical meteorological characteristics in Korea, where precipitation increases gradually from April and annual precipitation is concentrated during the summer months (June to August). Groundwater flux measured by each seepage meter (A, B, C, and D) during the study period shows large differences at each location, with only groundwater influx being observed within the range of $+2.2 \times 10^{-10}-+4.9 \times 10^{-8} \mathrm{~m} / \mathrm{s}$ $\left(+0.01 \mathrm{~L} / \mathrm{m}^{2} \mathrm{~d}-+4.19 \mathrm{~L} / \mathrm{m}^{2} \mathrm{~d}\right)$. Groundwater influx did not increase immediately after precipitation 
but increased gradually in response to the increased precipitation between the months of April and August. These results were similar to those of Lee et al. [13], who intensively measured groundwater flux once or twice a week during the rainy season of 2018, and showed average groundwater flux to be in the range of $+0.41-+4.13 \mathrm{~L} / \mathrm{m}^{2} \mathrm{~d}$. The results of this earlier study and the present one confirm that groundwater influx occurs in the upgradient of Osongji, where the seepage meters were installed.

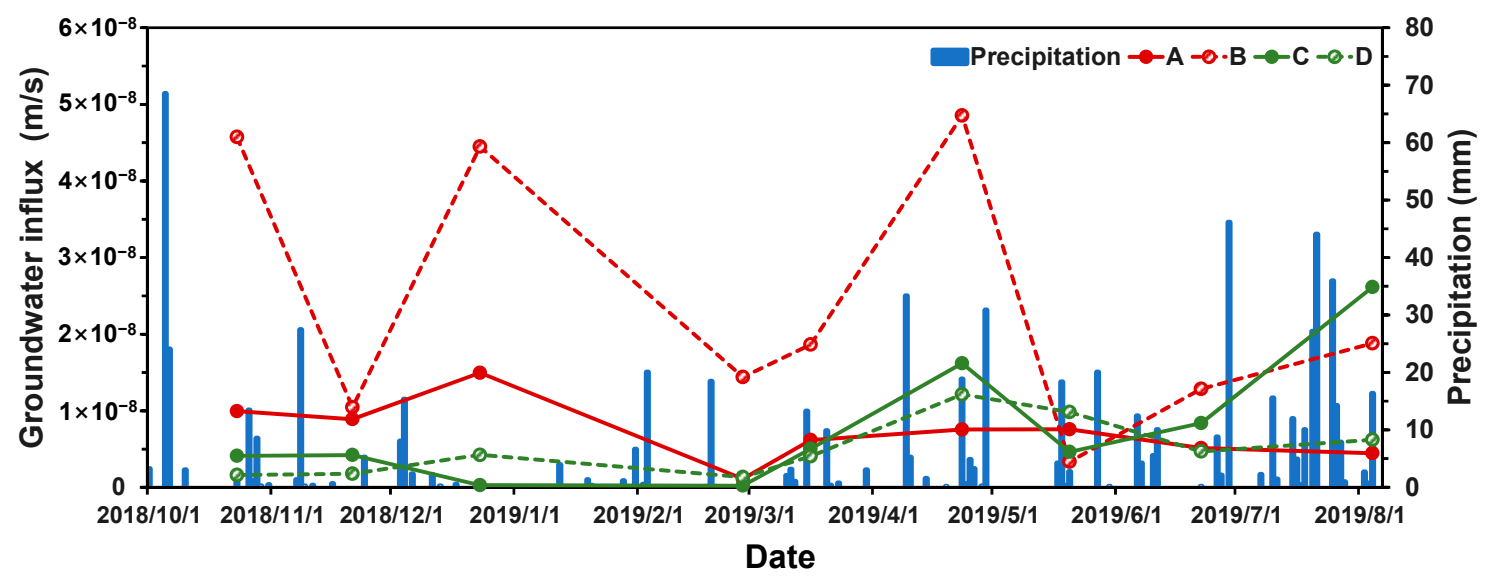

Figure 2. Comparison of groundwater influx per unit area at Osongii with precipitation between October 2018 and August 2019.

Although the groundwater influx measured at each seepage meter (A, B, C, and D) showed large differences, the increasing and decreasing patterns over time were similar, with a few exceptions for seepage meter $C$. The average groundwater influx measured at seepage meters $A$ and $B$ installed in Area 1 was $7.3 \times 10^{-9}$ and $2.4 \times 10^{-8} \mathrm{~m} / \mathrm{s}$, respectively, which was larger than that measured at seepage meters $C$ and $D$ installed in Area $2\left(7.7 \times 10^{-9}\right.$ and $5.1 \times 10^{-9} \mathrm{~m} / \mathrm{s}$, respectively). The differences in the measured influx at each point may represent the differences in hydraulic conductivity resulting from the heterogeneity of the lakebed sediments. The difference in groundwater influx between Area 1 and Area 2 may also reflect topography of Osongji itself, given that the slope of the drainage area on the side of Area 1 is higher than that of Area 2.

Due to the fact that groundwater influx responded gradually to precipitation, it was speculated that some time may be required for groundwater inflow to take place after precipitation, although groundwater flow paths may be different depending on the location of rainwater infiltration. To investigate whether there was a correlation between precipitation and groundwater influx, cumulative precipitation data from 1 to 4 months prior to the day on which groundwater flux was measured were compared with the groundwater influx measured on the day itself. A very weak positive or no correlation was observed between cumulative precipitation over the two months prior to the day when groundwater flux was measured and the measured groundwater flux itself (figure not shown; linear correlation coefficient $\left(\mathrm{r}^{2}\right)$ of 0.09$)$. The correlation was slightly higher for the monthly period between the 3rd and 4th months prior to the day when groundwater flux was measured $\left(r^{2}\right.$ of 0.19$)$. Evaporation was not included in the correlation because no specific evaporation data for the lake was available.

The temporal variability of the seepage rate and precipitation suggests that groundwater influx depends on a number of complex factors, including the heterogeneity of the groundwater flowpath and the water balance in the watershed system, rather than simply being an immediate response to precipitation. Overall, these results suggest that Osongii is a system that is supplied with groundwater after precipitation in the watershed, and that the recharged groundwater stays in the aquifer for some time before entering the lake. This is consistent with the results from the previous study of Lee et al. [13] in that groundwater flux and precipitation are not strongly correlated to each other and groundwater flux into the lake may be delayed after rainwater infiltration. 


\subsection{Water Levels and Grain Size Distribution}

The groundwater and surface water levels measured automatically using the CTD-Diver in Area 1 from April 20 to August 6, 2019 are presented in Figure 3a. The head differences between groundwater and surface water are shown in Figure 3b, along with the groundwater fluxes measured by seepage meters A and B. The temporal changes in groundwater and surface water levels are generally consistent with precipitation (Figure 2). The groundwater level was continuously measured higher than the surface water level, with an average head difference of $0.54 \mathrm{~cm}$. This supports the results of the seepage meter measurement, confirming that groundwater flows into surface water in the measured area. It should be noted that the groundwater fluxes measured by the seepage meters are average values over around 3 days, whereas the water levels reflect the head differences at the time of measurement.

(a)

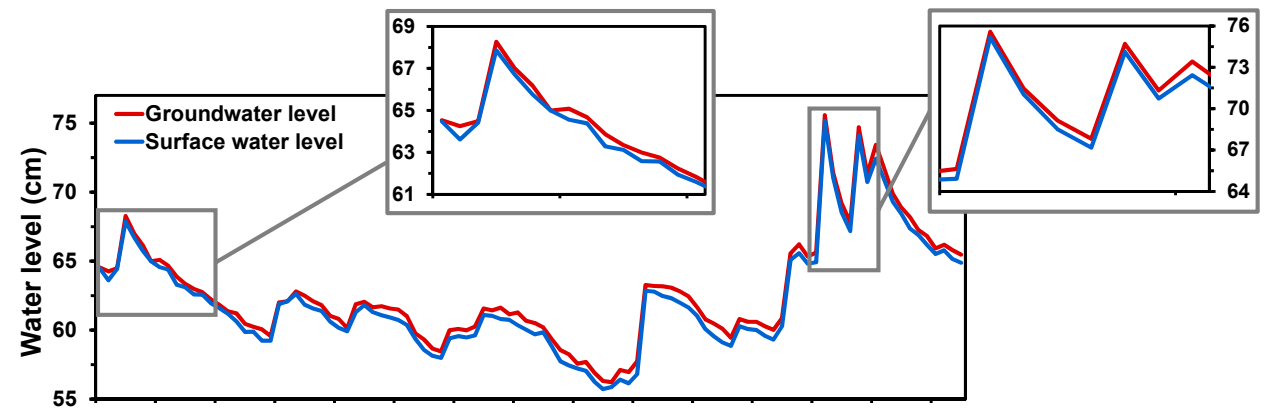

(b)

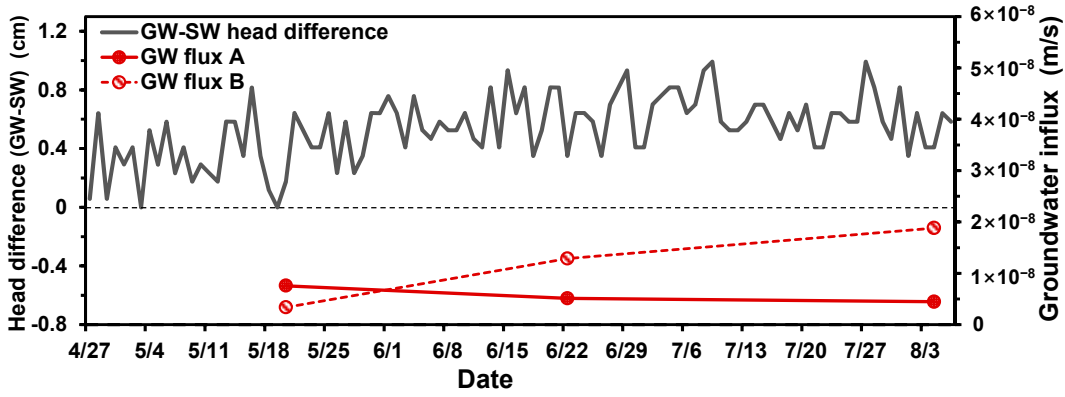

Figure 3. (a) Groundwater and surface water levels measured in 2019 using the CTD-Diver in Area 1. (b) Head difference between groundwater and surface water (GW-SW) with groundwater fluxes (A and B) measured in Area 1.

Based on the grain size classification suggested by Wentworth [40], the results of the grain size analysis showed that the lake sediment in Area 1 consists of $1.0 \%$ of gravel, $36.9 \%$ coarse to medium sand, $28.9 \%$ fine sand, and 33.2\% silt and clay, while in Area 2 it consists of $5.3 \%$ of gravel, 33.0\% coarse to medium sand, $33.9 \%$ fine sand, and $27.9 \%$ silt and clay. A hydraulic conductivity calculation using grain size analysis was not possible, however, because the effective grain diameter [41] could not be determined due to the fine particle size of the sediment.

\subsection{Aqueous Chemistry}

Results of the water quality analysis for surface water and groundwater in Osongji are summarized in Tables S1 and S2, respectively. DO values for most of the surface water (S1, S2, S3) ranged from 9.4 to $10.1 \mathrm{mg} / \mathrm{L}$, while those of groundwater (G1, G2) in Area 1 were 6.3-6.8 mg/L. The groundwater $(\mathrm{G} 3, \mathrm{G} 4)$ in Area 2 showed a low DO value, with a range of $1.1-1.7 \mathrm{mg} / \mathrm{L}$. It should be noted that the DO values of groundwater might be affected by the aeration of samples during the sampling procedure using the Wattera pump. The results of the DO measurement show that, unlike the environment of surface water, which is open to the atmosphere, groundwater is under a more closed environment with a locally more reduced condition, as is the case in Area 2 (Figure 4a). 
Surface water
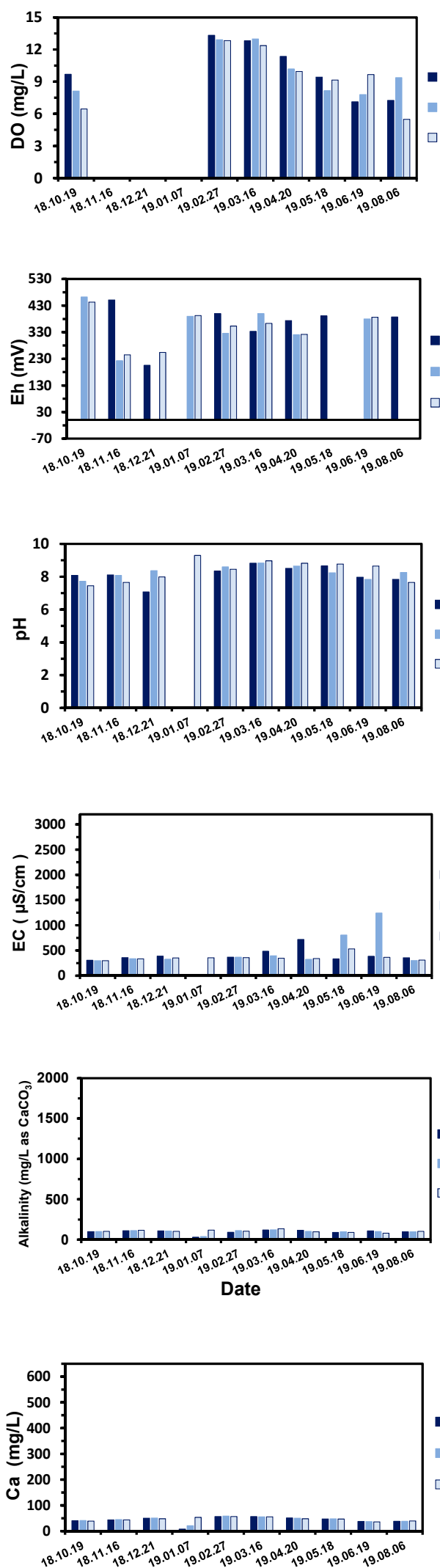

Groundwater

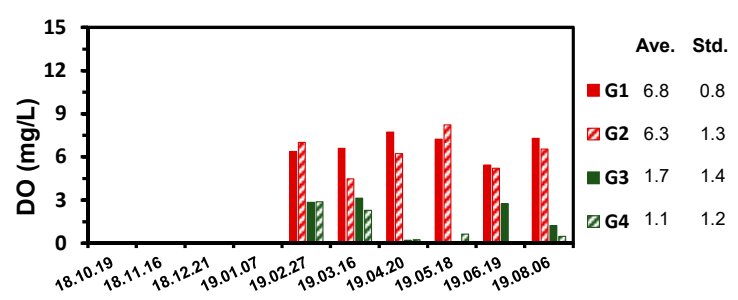

(a) $\mathrm{DO}$

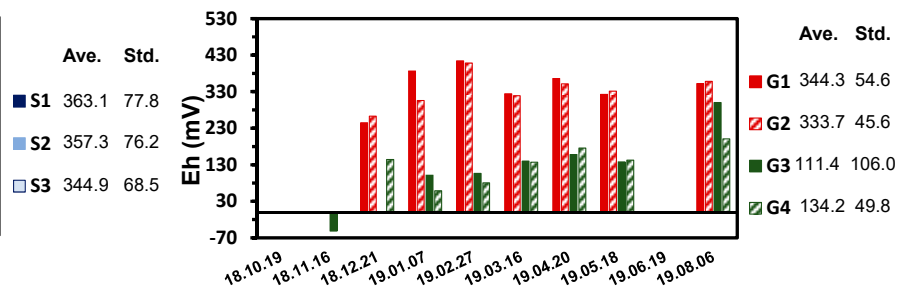

(b) Eh

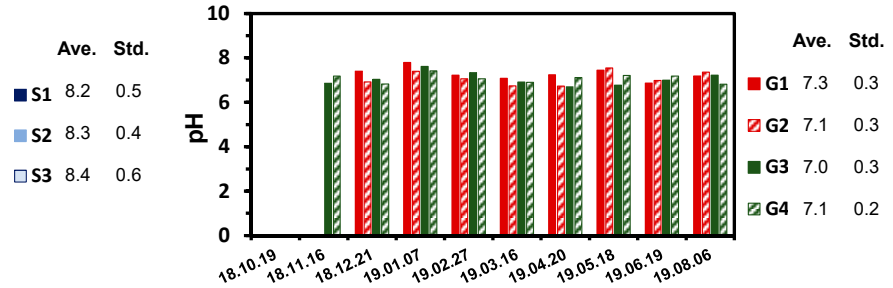

(c) $\mathrm{pH}$

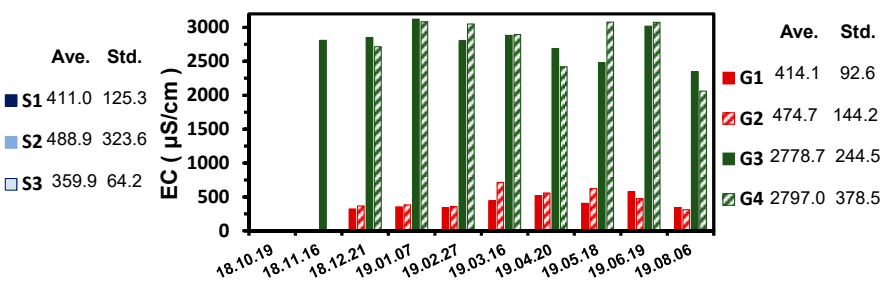

(d) EC

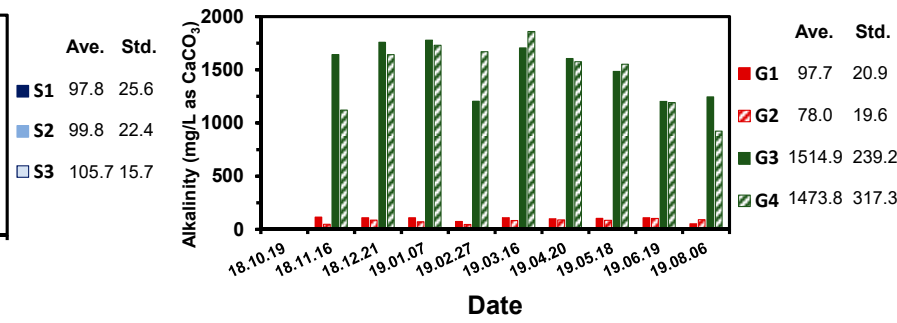

(e) Alkalinity

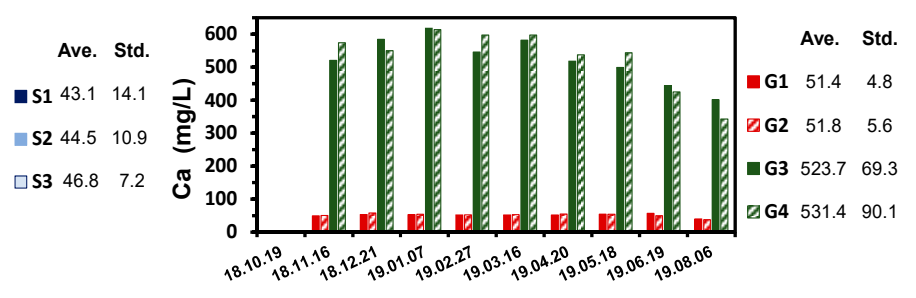

(f) $\mathrm{Ca}$

Figure 4. Cont. 

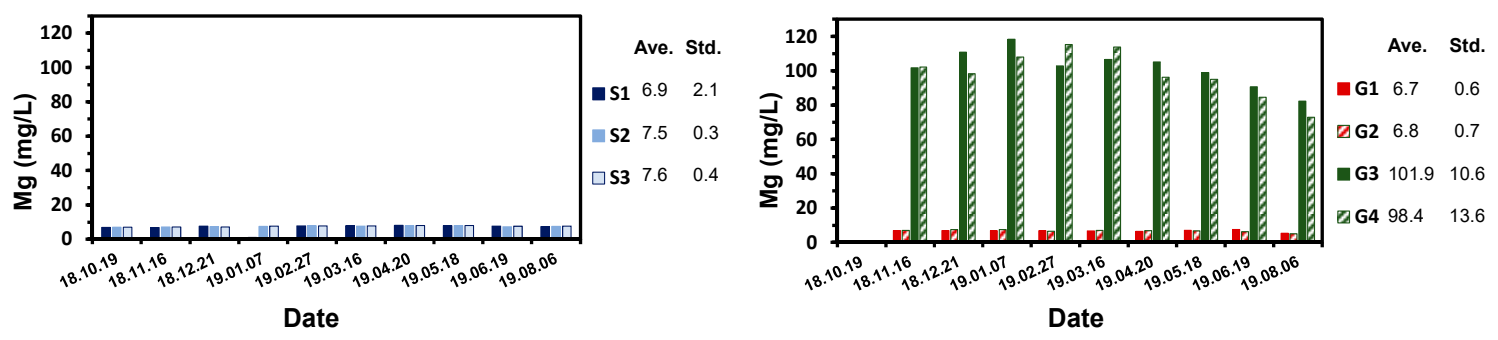

(g) $\mathrm{Mg}$

Figure 4. (a) Dissolved oxygen (DO), (b) Eh, (c) pH, (d) electrical conductivity (EC), (e) alkalinity, (f) Ca, and (g) Mg concentrations of surface water (S1-S3) and groundwater (G1-G4) between October 2018 and August 2019. Due to a probe malfunction, DO was not measured for samples collected between November 2018 and January 2019.

Eh values corresponded closely with $\mathrm{DO}$ values, falling within the range of 344.9-363.1 $\mathrm{mV}$ in surface water, 333.7-344.3 $\mathrm{mV}$ in the groundwater of Area 1, and 111.4-134.2 $\mathrm{mV}$ in the groundwater of Area 2 (Figure $4 \mathrm{~b}$ ). This indicates that the surface water environment is more oxidizing than the groundwater environment, and also that the groundwater environment in Area 2 is more reduced than that of Area 1.

$\mathrm{pH}$ measurements for surface water were mostly in the range of $\mathrm{pH} 8.2-8.4$. Groundwater $\mathrm{pH}$ values were in the range of 7.0-7.3, slightly lower than those of surface water. Groundwater $\mathrm{pH}$ values did not differ significantly in different locations (Figure 4c).

The EC values of surface water ranged from 359.9 to $488.9 \mu \mathrm{S} / \mathrm{cm}$, similar to those of the groundwater in Area $1(414.1-474.7 \mu \mathrm{S} / \mathrm{cm})$, while those of the groundwater in Area 2 were very high, ranging from 2778.7 to $2797.0 \mu \mathrm{S} / \mathrm{cm}$. Groundwater and surface water EC values showed slight changes over time as well as clear spatial differences, particularly for groundwater, suggesting that groundwater composition is largely affected by local geochemical reactions (Figure 4d).

Alkalinity values were $97.8-105.7 \mathrm{mg} / \mathrm{L}$ as $\mathrm{CaCO}_{3}, 78.0-97.7 \mathrm{mg} / \mathrm{L}$ as $\mathrm{CaCO}_{3}, 1473.8-1514.9 \mathrm{mg} / \mathrm{L}$ as $\mathrm{CaCO}_{3}$ for the surface water and groundwater in Area 1 and Area 2, respectively (Figure 4e). The high alkalinity for groundwater in Area 2 is considered to be due to the fact that the bedrock of Area 2 is mainly composed of carbonates. Concentrations of $\mathrm{Ca}$ and $\mathrm{Mg}$ at each site showed similar tendencies to those of alkalinity, showing noticeably higher values in the groundwater in Area 2 than the surface water and groundwater in Area 1 (Figure 4f,g). Ca concentrations were $43.1-46.8 \mathrm{mg} / \mathrm{L}$ for the surface water, and $51.4-51.8 \mathrm{mg} / \mathrm{L}, 523.7-531.4 \mathrm{mg} / \mathrm{L}$ for the groundwater in Area 1 and Area 2, respectively. $\mathrm{Mg}$ concentrations were in the range of $6.9-7.6 \mathrm{mg} / \mathrm{L}, 6.7-6.8 \mathrm{mg} / \mathrm{L}, 98.4-101.9 \mathrm{mg} / \mathrm{L}$ for the surface water and groundwater in Area 1 and Area 2, respectively. The concentrations of alkalinity, $\mathrm{Ca}$, and $\mathrm{Mg}$ showed gradual decreases during the rainy season (from April to August); this may be due to the fact that the major components of the groundwater were diluted by the heavy rainfall during the summer season.

The results of major cation and anion analysis for groundwater and surface water are plotted on a Piper diagram to evaluate the differences in characteristics of major elements (Figure 5). Surface water samples (S1, S2, and S3) showed similar compositions, and were represented by $\mathrm{Ca}^{2+}+\mathrm{HCO}_{3}{ }^{-}$type. The groundwater in Area 1 samples (G1 and G2) showed $\mathrm{Ca}^{2+}+\mathrm{HCO}_{3}{ }^{-}$type to $\mathrm{Ca}^{2+}+\mathrm{SO}_{4}{ }^{2-}$ type. The groundwater in Area 2 (G3 and G4) was represented by $\mathrm{Ca}^{2+}+\mathrm{HCO}_{3}{ }^{-}$type, with a particularly low concentration of $\mathrm{SO}_{4}{ }^{2-}$ among the anion components. In general, $\mathrm{Ca}^{2+}+\mathrm{HCO}_{3}{ }^{-}$type represents characteristics in areas composed of dolomite or limestone and is considered to be affected by chemical weathering or water-rock interactions [9]. The composition of the groundwater in Area 2 may represent local geochemical characteristics of bedrock composed of carbonates, which is consistent with the high concentrations of alkalinity, $\mathrm{Ca}$, and, $\mathrm{Mg}$ (Figure 4e-g). On the Piper diagram, it appears that the surface water composition is located between the compositions of two groundwaters in Area 1 and Area 2 (Figure 5); however, the major composition of surface water may not represent simple mixing of 
rainwater and the two groundwaters in Area 1 and Area 2. Artificial contamination from agricultural activities might also contribute to the lake surface water composition. In particular, surface water samples in January 2019 were collected from the ice layer (see Table S1); this might cause additional artifacts for the chemical composition of surface water.

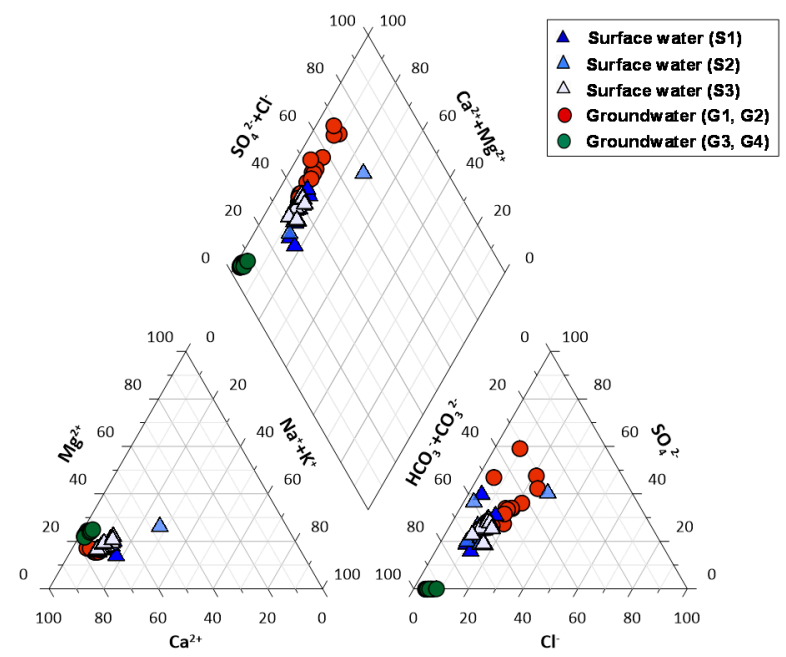

Figure 5. Piper diagram for major cations and anions of groundwater and surface water at Osongji.

Concentrations of alkalinity, $\mathrm{Ca}$, and $\mathrm{Mg}$ were higher in groundwater than those in surface water (Figure $4 \mathrm{e}-\mathrm{g}$ ). In addition, relatively high concentrations of trace elements (i.e., Si, Fe, Mn, and Sr), which can originate from source rocks, were detected in groundwater, whereas low concentrations were detected in surface water (Figure 6). The differences in the water quality of groundwater in different locations are due to the differing geological properties of bedrocks. The bedrock of Area 1 consists of metamorphic rock stratum, which is composed of phyllite and quartz schist, whereas the bedrock of Area 2 is composed of limestone as well as phyllite and quartz schist [37].

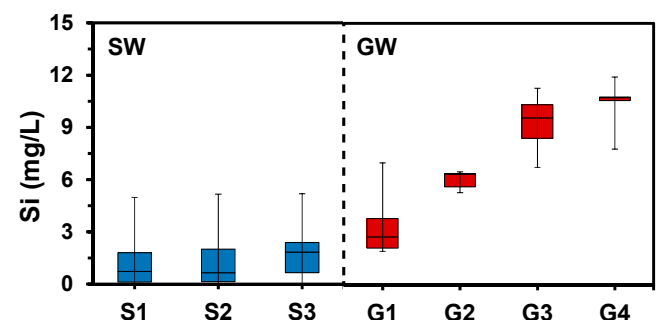

(a) $\mathrm{Si}$

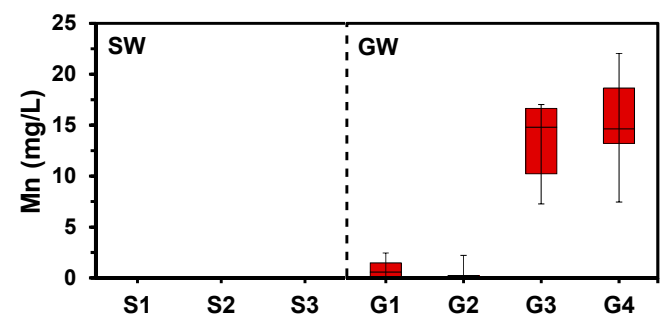

(c) $\mathrm{Mn}$

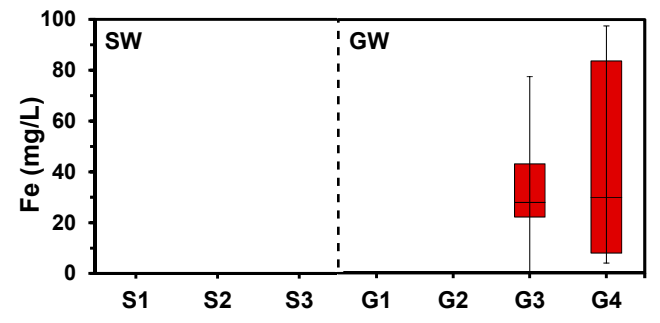

(b) Fe

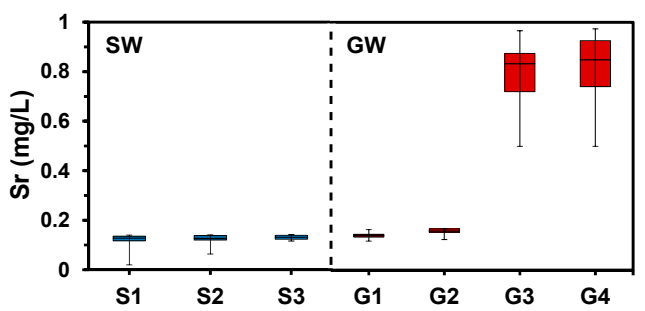

(d) $\mathrm{Sr}$

Figure 6. Box and whisker plots of concentrations of (a) Si, (b) Fe, (c) Mn, and (d) Sr of surface water (S1-S3) and groundwater (G1-G4). The five horizontal lines represent minimum, 25th percentile, median, 75th percentile and maximum values, respectively. 
The water quality characteristics of groundwater differed further depending on redox conditions (i.e., Area 1 vs. Area 2). The groundwater in Area 2 showed relatively high concentrations of alkalinity (Figure 4e) and low DO and Eh values compared to that in Area 1 (Figure 4a,b). Geochemical reactions that can consume oxygen and produce alkalinity may be related to the decomposition of organic substances in Area 2. This explanation is supported by Figure 7, which shows concentrations of $\mathrm{DO}, \mathrm{NO}_{3}, \mathrm{Mn}, \mathrm{Fe}$ and $\mathrm{SO}_{4}$ for groundwater. In a typical redox environment in groundwater, after dissolved oxygen is completely consumed by reactions such as the decomposition of organic substances, $\mathrm{NO}_{3}$ concentration decreases. As the more reduced environment develops, concentrations of $\mathrm{Mn}$ and $\mathrm{Fe}$ increase, after which the concentration of $\mathrm{SO}_{4}$ decreases [42]. The higher concentrations of dissolved oxygen and $\mathrm{NO}_{3}$ in Area 1 indicate that the environment in Area 1 has more oxidizing conditions than in Area 2, which shows lower concentrations of $\mathrm{DO}$ and $\mathrm{NO}_{3}$ and higher concentrations of $\mathrm{Mn}$ and $\mathrm{Fe} . \mathrm{SO}_{4}$ in Area 2 was detected at a very low concentration, suggesting that this area may be under sulfate-reducing conditions, although this requires further investigation. The differences in groundwater characteristics between Area 1 and Area 2 may represent local heterogeneity in sediment properties, such as enriched organic content, which also merits further investigation.

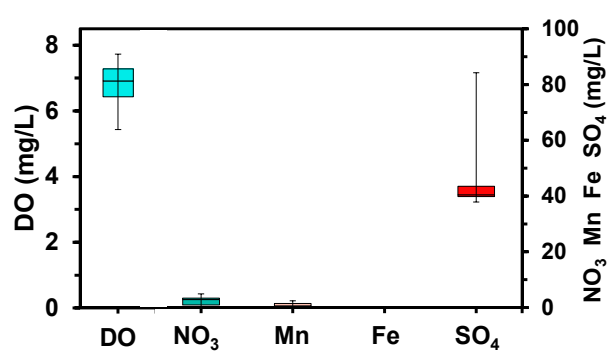

(a) G1

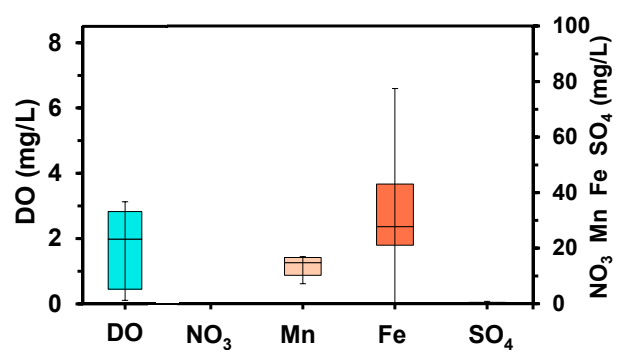

(c) G3

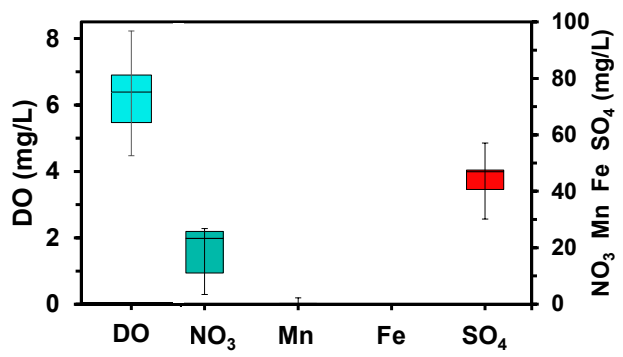

(b) G2

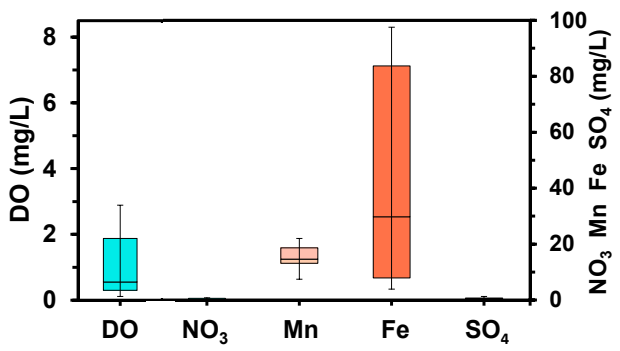

(d) G4

Figure 7. Box and whisker plots of the groundwater compositions ( $\mathrm{DO}, \mathrm{NO}_{3}, \mathrm{Mn}, \mathrm{Fe}, \mathrm{SO}_{4}$ ) at each point (G1-G4; (a-d)). The five horizontal lines represent minimum, 25th percentile, median, 75th percentile and maximum values, respectively.

In summary, the aqueous chemistry of Osongji clearly indicates differences in composition between surface water and groundwater. The water quality characteristics of surface water were found to be closer to those of the groundwater in Area 1 than Area 2. This result is consistent with the observation that groundwater influx from Area 1 is higher than from Area 2. The differences in groundwater quality between Area 1 and Area 2 also indicate that the hydrochemical characteristics of groundwater are greatly affected by geological features, subsurface redox conditions, and/or artificial contamination.

\subsection{Isotopic Compositions of Water Components}

The isotopic compositions of groundwater showed slight variation within a range of $-52.4 \%$ o- $-40.9 \%$ ond $-7.8 \%$ o- $-6.1 \%$ o for hydrogen and oxygen isotopes, respectively (Table 1 and Figure 8 ). On the other hand, those of surface water varied widely within a range of $-55.7 \%$ o- $-38.3 \%$ o 
and $-7.8 \% \mathrm{o}_{-}-4.7 \%$, for hydrogen and oxygen, respectively. The isotopic composition of rainwater showed a larger variation than those of groundwater and surface water and had a range of $-76.2 \%$ o- $18.6 \%$ ond $-9.8 \%$ o-9.1\%o for hydrogen and oxygen isotopes, respectively. The isotopic composition of surface water varied depending on the season (Figure 8). The isotopic compositions of groundwater and surface water were similar in autumn (October to November) and winter (December to February), when precipitation was relatively low. The isotopic composition of surface water gradually approached that of rainwater in spring (March to May) and summer (June to August), when precipitation increases. This result reflects the fact that the hydrogen and oxygen isotopic composition of surface water, which is affected both by groundwater and rain water, is generally located between those of groundwater and rain water [43].

Table 1. $\delta \mathrm{D}$ and $\delta^{18} \mathrm{O}$ isotopic compositions of groundwater, surface water and rainwater in the study site.

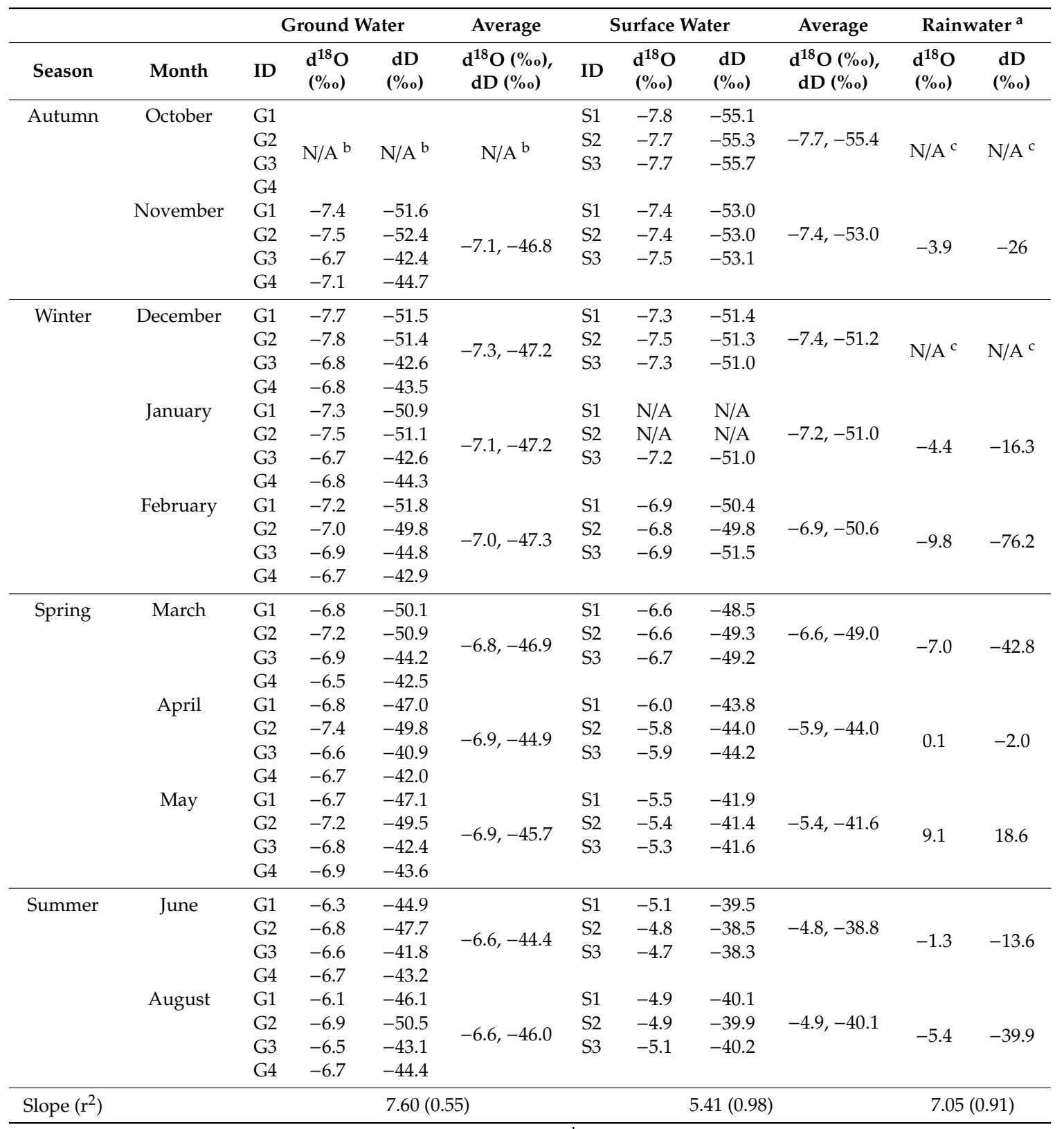

N/A: Not applicable. ${ }^{a}$ Rainwater was collected for a month. ${ }^{b}$ Groundwater samples were not collected from all piezometers in October 2018. ${ }^{c}$ Rainwater samples were not collected in October and December 2018. 


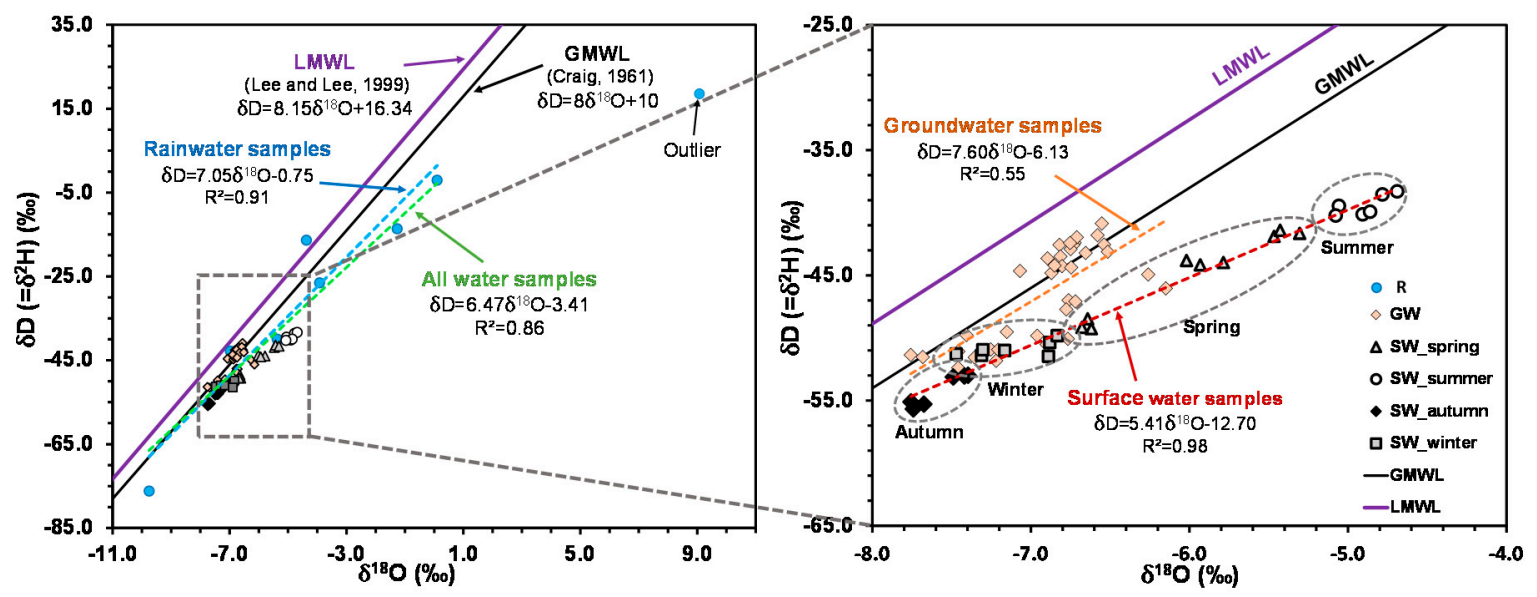

Figure 8. Hydrogen and oxygen isotopic composition of groundwater (GW), surface water (SW), and rainwater (R), shown with global meteoric water line (GMWL) [39] and local meteoric water line (LMWL) [44]. Surface water shows seasonal variation in isotopic composition (indicated by groups of autumn, winter, spring, and summer).

The isotopic composition of rainwater in the study area was enriched in summer and depleted in winter (Table 1). This result is consistent with the isotopic characteristics of the most mid-latitude area within eastern Asia [45]. The hydrogen and oxygen isotopic compositions of groundwater, surface water, and rainwater samples from October 2018 to August 2019 are shown in Figure 8, along with the GMWL [39] and the local meteoric water line (LMWL) in Korea [44]. The slopes of hydrogen and oxygen isotopic compositions were $7.60\left(\mathrm{r}^{2}=0.55 ; n=36\right)$ for groundwater, $5.41\left(\mathrm{r}^{2}=0.98 ; n=28\right)$ for surface water, and $7.05\left(\mathrm{r}^{2}=0.91 ; n=7\right)$ for rainwater. The rainwater outlier sample, collected in May 2019, was excluded from the slope calculation because excessive evaporation was deemed to have occurred during the sampling procedure, in spite of the mineral oil film on the water surface. The slope of $6.47\left(\mathrm{r}^{2}=0.86 ; n=71\right)$ for all water samples showed a lower slope compared to the GMWL with a slope of 8.0, and to the LMWL with a slope of 8.15 (Figure 8). The LMWL represents the isotopic composition in some regions of Korea, including Seoul, Daejeon, and Injae. The LMWLs in Korea previously defined in Seoul, Jeju island, Pohang, and Chuncheon had slopes of 8.0 [46], 8.05 [47], and 8.06 [48], respectively. In addition, for the rainwater samples in Korea, deuterium excess values $\left(\mathrm{d}=\delta \mathrm{D}-8 \delta^{18} \mathrm{O}\right)$ exhibit a distinctive seasonal variation: low in summer (around $+10 \%$ ) and high in winter (around $+20 \%$ ) [45]. Based on previous studies of isotopic composition in Korea, the samples of groundwater, surface water, and rainwater collected in this study might experience fractionation, probably due to evaporation during the sampling period.

The results from the seepage meter measurement and isotope analysis help the understanding of the water system in Osongji. While absolute groundwater influx increased as the amount (or frequency) of precipitation increased during the summer (Figure 2), the isotopic composition of surface water approached that of rainwater as precipitation increased, suggesting that the relative contribution of groundwater to surface water decreases as the contribution of rainwater increases (Table 1 and Figure 8). This implies that absolute groundwater flux is not necessarily representative of the contribution of groundwater to surface water. Chemical and isotopic compositions can be diluted with increased precipitation, while groundwater influx can increase in proportion to the amount of precipitation. Therefore, this study demonstrates the utility of an integrated approach that combines water quantity and quality analysis in understanding a water system.

\section{Conclusions}

In this study, both water quantity and quality were analyzed for 11 months in 2018 and 2019 at Osongji, Jeonju-si, Jeollabuk-do, Korea, to evaluate the temporal contribution of groundwater 
to surface water. The results of groundwater flux measurement by four seepage meters installed at the upgradient of the lake showed that groundwater influx only occurred within the range of

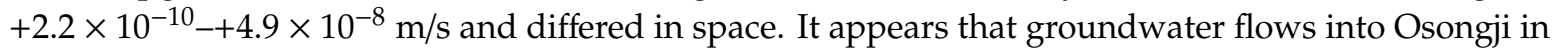
the form of baseflow, after water from precipitation flows through the aquifer with some residence time. Water level measurements confirmed that the groundwater level was higher than the surface water level, which is consistent with the results of the seepage meter measurement. However, with only four seepage meters installed in the upgradient of the lake and potential groundwater outflux beneath the dam in addition to the lack of surface water outflow measurement, it was not possible to accurately calculate the water balance of the lake system, which is beyond the scope of this study. Further investigation is required to have an accurate water balance for the lake system; it includes more prolonged and broad measurements of fluxes for both groundwater and surface water.

On-site water quality parameter analysis showed the distinctive water quality characteristics of surface water and groundwater. The major composition of surface water was mostly between those of the two groundwater compositions. This indicates that the hydrogeochemical characteristics of surface water are substantially affected by groundwater. Moreover, groundwater chemistry reflected water-rock interactions as well as different redox conditions at different locations of the lake. The results of the isotope analysis showed that the composition of surface water gradually approaches that of rainwater in the wet season, suggesting that the relative contribution of groundwater to surface water becomes lower due to the dilution with the increased amount of precipitation, while the absolute groundwater influx increases. Although this study indicates the variation in the isotopic composition of surface water depending on seasons, isotopic data of less than 1 year may not be sufficient to fully elucidate the significance of groundwater contribution to the lake system. Longer monitoring, perhaps more than two cycles of year-round investigations, will be beneficial to conclusively determine the temporal variations of groundwater contribution to the lake system.

An integrated interpretation that combines both water quantity and quality analysis is helpful to understanding a stable water system such as Osongii. Groundwater influx did not occur immediately after precipitation but increased gradually as precipitation increased. However, the relative contribution of groundwater to surface water decreased as precipitation increased. It is suggested that groundwater flux measurement and chemical and isotope analysis can be used effectively in the study of the groundwater-surface water interaction. The approach used here can thus be applied in other studies seeking to evaluate the importance of groundwater baseflow.

Supplementary Materials: The following are available online at http://www.mdpi.com/2073-4441/12/10/2879/s1, Table S1: On-site water quality parameters and major ion concentrations for surface waters (S1-S3), Table S2: On-site water quality parameters and major ion concentrations for groundwater (G1-G4).

Author Contributions: J.K.: Methodology, Formal analysis, Investigation, Writing —original draft preparation, Visualization; S.-W.J.: Conceptualization, Writing-review and editing, Supervision, Project administration, Funding acquisition; J.L.: Methodology, Formal analysis, Writing-review and editing; K.-S.K.: Resources, Writing-review and editing; D.-C.K.: Resources, Writing-review and editing; W.K.: Methodology, Validation; H.J.: Methodology, Validation. All authors have read and agreed to the published version of the manuscript.

Funding: This research was supported by the National Research Foundation of Korea (NRF) grant funded by the Ministry of Science and ICT (NRF-2019R1A2C1086667) and by the Polar Academic Program (PE20900) of the Korea Polar Research Institute.

Conflicts of Interest: The authors declare no conflict of interest.

\section{References}

1. Born, S.M.; Smith, S.A.; Stephenson, D.A. Hydrogeology of glacial-terrain lakes, with management and planning applications. J. Hydrol. 1979, 43, 7-43. [CrossRef]

2. Winter, T.C.; Harvey, J.W.; Franke, O.L.; Alley, W.M. Ground Water and Surface Water: A Single Resource; U.S. Geological Survey (USGS): Reston, VA, USA, 1998; Volume 1139.

3. Downing, J.A.; Peterka, J.J. Relationship of rainfall and lake groundwater seepage. Limnol. Oceanogr. 1978, $23,821-825$. 
4. Barkle, G.F.; Stenger, R.; Burgess, C.; Wall, A. Quantifying groundwater contribution to stream flow generation in a steep headwater catchment. J. Hydrol.: New Zealand 2014, 53, 23-40.

5. Orlova, J.; Branfireun, B.A. Surface water and groundwater contributions to streamflow in the James Bay Lowland, Canada. Arct. Antarct. Alp. Res. 2014, 46, 236-250. [CrossRef]

6. Choi, Y.H.; Park, Y.S.; Ryu, J.; Lee, D.J.; Kim, Y.S.; Choi, J.; Lim, K.J. Analysis of baseflow contribution to streamflow at several flow stations. J. Geol. Soc. Korea 2014, 30, 441-451, (In Korean with English abstract). [CrossRef]

7. Hagerthey, S.E.; Kerfoot, W.C. Groundwater flow influences the biomass and nutrient ratios of epibenthic algae in a north temperate seepage lake. Limnol. Oceanogr. 1998, 43, 1227-1242. [CrossRef]

8. Rozemeijer, J.C.; Broers, H.P. The groundwater contribution to surface water contamination in a region with intensive agricultural land use (Noord-Brabant, The Netherlands). Environ. Pollut. 2007, 148, 695-706. [CrossRef]

9. Shaw, G.D.; White, E.S.; Gammons, C.H. Characterizing groundwater-lake interactions and its impact on lake water quality. J. Hydrol. 2013, 492, 69-78. [CrossRef]

10. Meinikmann, K.; Hupfer, M.; Lewandowski, J. Phosphorus in groundwater discharge-A potential source for lake eutrophication. J. Hydrol. 2015, 524, 214-226. [CrossRef]

11. Zhu, D.; Ryan, M.C.; Sun, B.; Li, C. The influence of irrigation and Wuliangsuhai Lake on groundwater quality in eastern Hetao Basin, Inner Mongolia, China. Hydrogeol. J. 2014, 22, 1101-1114. [CrossRef]

12. Kalbus, E.; Reinstorf, F.; Schirmer, M. Measuring methods for groundwater-Surface water interactions: A review. Hydrol. Earth Syst. Sci. 2006, 10, 873-887. [CrossRef]

13. Lee, C.; Kim, W.; Jeen, S.-W. Analysis of water budget through measurement of groundwater flux using seepage meters at Osongji in Jeonju-si. J. Geol. Soc. Korea 2019, 55, 461-472, (In Korean with English abstract). [CrossRef]

14. Lee, D.R. A device for measuring seepage flux in lakes and estuaries. Limnol. Oceanogr. 1977, $22,140-147$. [CrossRef]

15. Lawrence, C.; Murdoch, L.C.; Kelly, S.E. Factors affecting the performance of conventional seepage meters. Water Resour. Res. 2003, 39, 424.

16. Rosenberry, D.O. Seepage meter designed for use in flowing water. J. Hydrol. 2008, 359, 118-130. [CrossRef]

17. Vogt, T.; Schneider, P.; Hahn-Woernle, L.; Cirpka, O.A. Estimation of seepage rates in a losing stream by means of fiber-optic high-resolution vertical temperature profiling. J. Hydrol. 2010, 380, 154-164. [CrossRef]

18. Lee, D.R.; Cherry, J.A. A field exercise on groundwater flow using seepage meters and minipiezometers. J. Geol. Educ. 1978, 27, 6-10. [CrossRef]

19. Rautio, A.; Korkka-Niemi, K. Characterization of groundwater-lake water interactions at Pyhäjärvi, a lake in SW Finland. Boreal Environ. Res. 2011, 16, 363-380.

20. Chen, X.; Song, J.; Cheng, C.; Wang, D.; Lackey, S.O. A new method for mapping variability in vertical seepage flux in streambeds. Hydrogeol. J. 2009, 17, 519-525. [CrossRef]

21. Brodie, R.S.; Baskaran, S.; Ransley, T.; Spring, J. Seepage meter: Progressing a simple method of directly measuring water flow between surface water and groundwater systems. Aust. J. Earth Sci. 2009, 56, 3-11. [CrossRef]

22. Kim, H.; Lee, J.Y.; Park, Y.; Hyun, Y.; Lee, K.K. Groundwater and stream water exchange revealed by water chemistry in a hyporheic zone of agricultural area. Paddy Water Environ. 2014, 12, 89-101. [CrossRef]

23. Klaus, J.; McDonnell, J.J. Hydrograph separation using stable isotopes: Review and evaluation. J. Hydrol. 2013, 505, 47-64. [CrossRef]

24. Jung, Y.Y.; Koh, D.C.; Lee, J.; Ko, K.S. Applications of isotope ratio infrared spectroscopy (IRIS) to analysis of stable isotopic compositions of liquid water. Econ. Environ. Geol. 2013, 46, 495-508, (In Korean with English abstract). [CrossRef]

25. Kim, H.; Cho, S.H.; Lee, D.; Jung, Y.Y.; Kim, Y.H.; Koh, D.C.; Lee, J. Old Water Contributions to a Granitic Watershed, Dorim-cheon, Seoul. J. Soil Groundw. Environ. 2015, 20, 34-40. [CrossRef]

26. Sklash, M.G.; Farvolden, R.N. The role of ground-water in storm runoff. J. Hydrol. 1979, 43, 45-65. [CrossRef]

27. Moore, R.D. Tracing runoff sources with deuterium and oxygen- 88 during spring melt in a headwater catchment, southern Laurentians, Quebec. J. Hydrol. 1989, 112, 135-148. [CrossRef] 
28. Hatch, C.E.; Fisher, A.T.; Revenaugh, J.S.; Constantz, J.; Ruehl, C. Quantifying surface water-groundwater interactions using time series analysis of streambed thermal records: Method development. Water Resour. Res. 2006, 42, W10410. [CrossRef]

29. Keery, J.; Binley, A.; Crook, N.; Smith, J.W. Temporal and spatial variability of groundwater-surface water fluxes: Development and application of an analytical method using temperature time series. J. Hydrol. 2007, 336, 1-16. [CrossRef]

30. Anderson, M.P. Heat as a ground water tracer. Ground Water 2005, 43, 951-968. [CrossRef]

31. Sacks, L.A.; Herman, J.S.; Konikow, L.F.; Vela, A.L. Seasonal dynamics of groundwater-lake interactions at Doñana National Park, Spain. J. Hydrol. 1992, 136, 123-154. [CrossRef]

32. Anderson, E.I. Modeling groundwater-surface water interactions using the Dupuit approximation. Adv. Water Resour. 2005, 28, 315-327. [CrossRef]

33. Saha, G.C.; Li, J.; Thring, R.W.; Hirshfield, F.; Paul, S.S. Temporal dynamics of groundwater-surface water interaction under the effects of climate change: A case study in the Kiskatinaw River Watershed, Canada. J. Hydrol. 2017, 551, 440-452. [CrossRef]

34. Chen, X.; Shu, L. Stream-aquifer interactions: Evaluation of depletion volume and residual effects from ground water pumping. Ground Water 2002, 40, 284-290. [CrossRef] [PubMed]

35. Woessner, W.W.; Sullivan, K.E. Results of seepage meter and mini-piezometer study, Lake Mead, Nevada. Ground Water 1984, 22, 561-568. [CrossRef]

36. Cey, E.E.; Rudolph, D.L.; Parkin, G.W.; Aravena, R. Quantifying groundwater discharge to a small perennial stream in southern Ontario, Canada. J. Hydrol. 1998, 210, 21-37. [CrossRef]

37. Choi, S.H.; Kim, S.H.; Lee, J.W.; Kim, K.J.; Oh, C.W. A study on obtaining waters to restore the water-ecosystem of Deokjin Pond in Jeonju: New paradigm for restoration of urban reservoirs. Econ. Environ. Geol. 2015, 48, 467-475, (In Korean with English abstract). [CrossRef]

38. Jo, I.; Jeen, S.-W. Measurement of groundwater-surface water exchange rates using seepage meters: A case study of Deokjin pond in Jeonju-si. J. Geol. Soc. Korea 2018, 54, 433-441, (In Korean with English abstract). [CrossRef]

39. Craig, H. Isotopic variations in meteoric waters. Science 1961, 133, 1702-1703. [CrossRef]

40. Wentworth, C.K. A scale of grade and class terms for clastic sediments. J. Geol. 1922, 30, 377-392. [CrossRef]

41. Vukovic, M.; Soro, A. Determination of Hydraulic Conductivity of Porous Media from Grain-Size Composition; Water Resources Publications: Littleton, CO, USA, 1992.

42. Appelo, C.A.J.; Postma, D. Geochemistry, Groundwater and Pollution, 2nd ed.; Balkema Publisher: Amsterdam, The Netherlands, 2005.

43. Lee, J. A review on hydrograph separation using isotopic tracers. J. Geol. Soc. Korea 2017, 53, $339-346$. (In Korean with English abstract). [CrossRef]

44. Lee, K.S.; Lee, C.B. Oxygen and hydrogen isotopic composition of precipitation and river waters in South Korea. J. Geol. Soc. Korea 1999, 35, 73-84. (In Korean with English abstract)

45. Posmentier, E.S.; Feng, X.; Zhao, M. Seasonal variations of precipitation $\delta^{18} \mathrm{O}$ in eastern Asia. J. Geophys. Res. Atmos. 2004, 109, D23106. [CrossRef]

46. Lee, K.S.; Grundstein, A.J.; Wenner, D.B.; Choi, M.S.; Woo, N.C.; Lee, D.H. Climatic controls on the stable isotopic composition of precipitation in Northeast Asia. Clim. Res. 2003, 23, 137-148. [CrossRef]

47. Lee, K.S.; Chung, J.I. Stable isotopic variation of precipitation in Pohang, Korea. Econ. Environ. Geol. 1997, 30, 321-325. (In Korean with English abstract)

48. Park, Y.; Lee, K.S.; Yu, J.Y. Seasonal variations of dissolved ions and oxygen and hydrogen isotopic compositions of precipitation in Chuncheon, Korea. J. Geol. Soc. Korea 2006, 42, 283-292. (In Korean with English abstract)

Publisher's Note: MDPI stays neutral with regard to jurisdictional claims in published maps and institutional affiliations. 